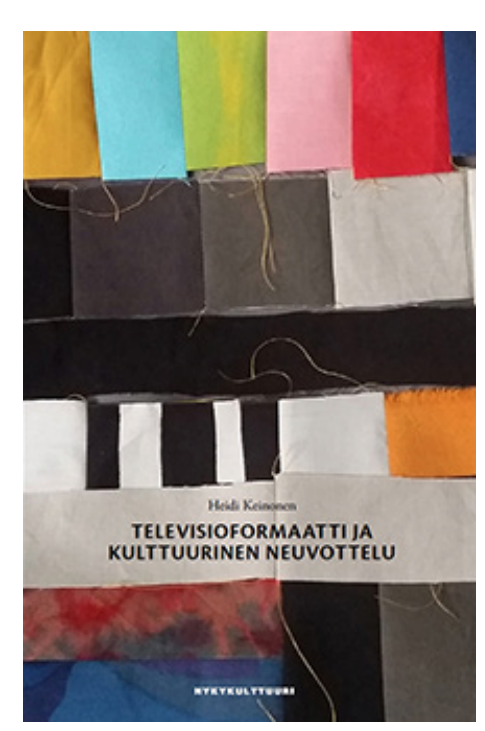

\section{TÄMÄ ON NYKYTELEVISIO}

Heidi Keinonen (2018): Televisioformaatti ja kulttuurinen neuvottelu. Nykykulttuurin tutkimuskeskuksen julkaisuja 123. Jyväskylän yliopisto. $231 \mathrm{~s}$.
Mediatutkija Heidi Keinosen uusi teos Televisioformaatti ja kulttuurinen neuvottelu fokusoituu television viimeaikaiseen muutokseen, mutta sen pontimena on historia. Otsikon mukaisesti televisioformaatit näyttäytyvät kulttuurisen neuvottelun areenoina.

Tekijän mukaan tutkimuksen tavoitteena on kertoa, mitä television ohjelmaformaatit ovat, mistä ne tulevat, miten niitä sovitetaan suomalaisiin tuotantoihin, ja ylipäätään selvittää sitä, millainen tv nykyisin on. Formaatin määrittelyyn Keinonen noutaa lukuisia apukäsitteitä, mutta hän muotoilee sen myös yksinkertaisesti. Formaatti voidaan nimetä ohjelmaideaksi, joka myydään versioitavaksi toiseen maahan. Se eroaa niin median tuotantoslangiin kuin mediatutkimukseen kuuluvista konseptin ja genren käsitteistä. Konseptilla voidaan tarkoittaa ideaa tai selostusta, mitä ohjelma sisältää ja millaiselle yleisölle se on tarkoitettu. Televisiotuotannoissa genre on kontekstisidonnainen ja katsojan ja tekijöiden vuorovaikutuksessa elävä sopimuksen kaltainen käytäntö. Sen sijaan aiemmin kirjallisuuden- ja elokuvatutkimuksen parissa genre on saattanut tarkoittaa hyvinkin formalistisesti lajinsisäisiä säännönmukaisuuksia.

Formaatin määrittelyä Keinonen jatkaa vertailuin formaattitutkimuksessa käytettyyn adaptaation käsitteeseen, jolla tarkoitetaan tvohjelman kulttuurista modifikaatiota. Formaatit luokitellaankin adaptaation asteen mukaan joko avoimiin tai suljettuihin. Termi on samalla tuotantotekninen. Suljettu formaatti sallii vain minimimäärän muokkaamista alkuperäisver- sion suhteen. Kuitenkin yleisimmin formaatti on hyvin pitkälti sovitettu kohdeyleisön kulttuuriin, jolloin se on avoin.

Keinonen muistuttaa, että televisiotutkimukseen 1980-luvun puolivälissä lanseerattu formaatin käsite ei tarkoita samaa kuin nykyisin. Suomessa vuonna 1988 formaatin käsitettä kirjassaan Formaatti ja televisiosarjat käsitellyt Dan Steinbock viittasi sillä eräänlaiseen prime time -ohjelmiin sisältyvään koodiin, joka tuotti samuutta ja toistoa. Steinbockin tulkinnassa toisteisuus toimi ohjelmien menestyksen takuuna.

\section{Televisio neuvotteluareenana}

Millainen on Keinosen kulttuurista neuvottelua korostava käsitys formaateista? Tulokulma probleemiin on miellyttävän selkeä. Kun tvyhtiöt työntekijöineen toimivat formaattien parissa, he sopivat asioista. Juuri tämä kommunikaatio kiinnostaa tutkijaa, ja sen ympärille hän rakentaa tutkimuksensa ytimen, jota hän kutsuu ohjelmasopimusten ympärillä käytäväksi kulttuuriseksi neuvotteluksi.

Kulttuurintutkimuksessa esiintyvä kulttuurisen neuvottelun käsite saattaa toisinaan olla metaforisuudessaan hieman hahmoton työväline. Joskus on epäselvää, ketkä tarkalleen ottaen neuvottelevat ja mistä. Tässä tapauksessa käsite on perusteltu ja rakentaa napakan jalustan etenemiselle. Yhtäältä formaattikaupassa osapuolet neuvottelevat ihan konkreettisesti muokattavista tuotteista ja so- 
pivat siitä, mitä voidaan tehdä ja mitä ei voida. Toisaalta, kuten Keinonen toteaa, televisiokulttuurit ovat historiallisesti muodostuneita, ja ne muuttuvat kansallisten kulttuurien sekä globaalien vaikutteiden vuorovaikutuksessa. Näin tarkastelussa kulkee mukana ajallinen ulottuvuus, jossa vaikutteet ovat liikkuneet ja liikkuvat monensuuntaisesti. Tässäkin on tapahtunut kaikenlaista kulttuurista sopimista.

Kun on kyse merkityksenantojen prosessista, mukana ovat ohjelmantekijöiden lisäksi vastaanottajat, yleisö. Varsinkin silloin, kun adaptaatioon vaikuttavia asioita analysoidaan ja kartoitetaan, tapahtuu eri tasoilla kulttuurista neuvottelua. Neuvottelumetaforan mukaan vastaanottajien (yleisö, fanit, kriitikot ja toimittajat) roolina olisi neuvotella tuotteen hyväksynnästä. Raadollisimmillaan se toteutuu joko hyväksymällä ohjelma tai hylkäämällä se. Yleisöjen ja vastaanoton analyysi ei ole kuitenkaan tutkimuksen keskiössä.

Keinonen ei myöskään varsinaisesti keskity yksittäisten formaattien analyyseihin, vaikka havainnollistavia esimerkkejä kirjasta löytyy. Esimerkkinä tuotantotapaformaatin siirrosta on MTV3:n sarja Salatut elämät, jonka kohdalla oli kyse tuotannon käytäntöjen siirrosta toiseen televisiokulttuuriin. Kiinnostava mediahistoriallinen tapaus on Suomen Yleisradion Tenavatuokio (1968-1969, 1973-1974), joka pohjautui yhdysvaltalaiseen Romper Roomiin. Se on mahdollisesti ensimmäinen virallisesti Suomeen lisensoitu ohjelmaformaatti. Tätä tapausta avataan ohjelmien, tuotantoaineistojen, haastattelujen, lehdistölähteiden ja ohjelmayhtiön materiaalien avulla.

Työtapaansa Keinonen kutsuu triangulaatioksi, jossa kaivetaan erilaisista lähteistä esille olennaisin tulkittavaksi. Tärkein lähderyhmä on Keinosen tekemät 14 teemahaastattelua, joissa 16 suomalaista tv-tuotantoammattilaista vastaavat ohjelmaformaatteja koskeviin kysymyksiin. Haastattelut on toteutettu aikavälillä 2014-15. Televisioyhtiöiden tuotantoammattilaiset edustavat kanavia Yle TV1, Yle TV2, MTV3, Sub, Ava, Nelonen, Liv, Jim, SBS Broadcasting Groupin TV Viisi ja Kutonen. Tuotantoyhtiöistä mukana olivat FremantleMedia Finland, Banijay Finland, Shine Finland ja Eyeworks Finland.

Laajemmin ymmärrettynä teos on mediateollisuuden tutkimusta, johon sisältyy media- tuotannon eri tasojen analyysejä ja historiaa. Työtapaansa ja etenemistään tutkija selittää huolellisesti, ja tutkimuksen tärkeänä ansiona pidänkin tutkimusapparaatin avaamista ja reflektiota. Tekijä haluaa problematisoida neuvottelun käsitteellä sitä, ettei adaptaatioissa ole kyse erillisten tv-kulttuurien tuotteiden sovittamisesta toiseen toimintaympäristöön vaan juuri aktiivisesta vuorovaikutuksesta.

Kirja sisältää kiinnostavaa suomalaisen television lähihistoriaa, jonka kehyksenä on muu maailma - onhan formaattikauppa osa television globalisoitumista ja sääntelyn purkua. Suomessa sysäyksiä ovat olleet Yleisradion, MTV:n ja Nokian omistaman Kolmoskanavan perustaminen vuonna 1986 sekä seuraavalla vuosikymmenellä aloittanut Nelonen. Se olikin Suomessa formaattien lanseeraamisen ja tuotannon ammattimaistumisen aikaa. 1990-luvun pioneeriohjelmia olivat muun muassa Onnenpyörä, Bumtsibum! ja Haluatko miljonääriksi? Formaattien tuonnin tärkeäksi aloitteentekijäksi tutkijan haastattelemat ammattilaiset nimesivät Broadcastersin, jonka ensimmäisiä adaptaatioita olivat Yle TV1:n televisioima Uutisvuoto ja MTV3:n Kokkisota.

Formaattikaupan kehitykselle oli suosiollista myös suomalaisen television digitalisoiminen, jonka myötä kanavia tuli lisää ja televisiotarjonta moninkertaistui. Kun kilpailu katsojista näin väistämättä koveni ja yleisö hajaantui eri kanaville, etsivät yhtiöt ratkaisua formaateista. Suomeen syntyi kohderyhmille suunnattuja kanavia, kuten Sub, Liv ja Ava. Vuonna 2005 alkaneen Big Brother -ohjelman myötä alettiin Suomessa vuosikymmenen lopulla siirtyä globaalin formaattikaupan aikaan, toteaa eräs Keinosen haastattelemista tv-alan ammattilaisista.

\section{Vuorovaikutusta on ollut aina}

Edellä kerrotut esimerkit kertovat tekijän asettaman tavoitteen mukaisesti suomalaisen television lähihistoriasta, mutta myös muusta. Keinonen on halunnut välttää metodologista nationalismia osoittamalla ohjelmien ja tuotantokäytäntöjen liikkuneen läpi kansallisten ja kulttuuristen rajojen läpi koko kotimaisen tv-toiminnan historian. Tuntuukin helpolta yhtyä toteamukseen, ettei "puhdasta" suomalaista televisiokulttuuria ole koskaan ollut 
olemassa. Vaikkei väite ole sinällään järisyttävä, on se hyödyllistä ilmaista perustelluilla argumenteilla.

Keinonen osoittaakin tuloksenaan, että kulttuuriset neuvottelut ovat olleet vähintään kaksisuuntaisia. Kun adaptaatio matkustaa toiseen kulttuuriin, se usein on muuttanut myös alkuperäistä formaattia. Juuri näistä neuvotteluista haastatellut todistavat. Käytännössä matkalla saattaa olla jatkuvasti muuttuva ohjelman muoto. Tämän lisäksi Keinosen julkilausumana tavoitteena on ollut osoittaa television rakenteiden globaalistuminen eritoten 2000-luvulla. Tämän rakenteiden havainnoinnin hän on onnistuneesti yhdistänyt toimijoiden ja käytäntöjen analyysiin. Vahvimman pohjan antavat juuri alan ammattilaisten todistukset.

Televisioformaatti ja kulttuurinen neuvottelu on paitsi tervetullut suomenkielinen analyysi television muutoksesta, se kertoo myös tv-am- mattilaisille oman alan muutoksesta. Lisäksi se epäilemättä soveltuu media-alan opiskelijoille oppaaksi nykytelevision maailmaan. Myös tutkimus on aikansa kuvastaja. Teos kuvastelee sitä, miten televisiobisneksessä on päädytty noin vuoden 2015 tilanteeseen. Keinonen painottaa toimialan hektistä rytmiä ja teknologian jatkuvaa muutosta. Mitä televisio voisi olla lähitulevaisuudessa? Jatkuuko globaalien formaattien voittokulku? Keinosen mukaan merkkejä on, että tuotantojen monimediaalisuus yleistyy ja kenties ikääntyville yleisöille lämmitetään entisiä formaatteja. Nimittäin tekijän mukaan uusia superformaatteja on viime aikoina syntynyt jo harvemmin.

\section{Paavo Oinonen}

FT, kulttuurihistoria, Turun yliopisto 